\title{
Laboreal
}

Volume $14 \mathrm{~N}^{\circ} 2$ | 2018

Digitalização e evolução do trabalho real

\section{Transição digital na construção civil: analisar a atividade de 'levantamento de inconformidades' mediada por um aplicativo informático de uma diretora de obra}

Transición digital en el sector de la construcción: analizar la actividad del 'levantamiento de reservas' mediada por una aplicación informática de una directora de obra

Transition numérique dans le bâtiment: analyser l'activité de 'levée de réserves' médiatisée par une application métier d'une conductrice de travaux Digital transition in the building industry: to analyze the construction site manager's activity of 'lifting of reservations' mediated by a business application

Elodie Chambonnière, Jacqueline Vacherand-Revel e Bruno Andrieu Tradutor. Laura Camara Lima

\section{OpenEdition} Journals

Edição electrónica

URL: http://journals.openedition.org/laboreal/629

DOI: $10.4000 /$ laboreal.629

ISSN: 1646-5237

\section{Editora}

Universidade do Porto

\section{Refêrencia eletrónica}

Elodie Chambonnière, Jacqueline Vacherand-Revel e Bruno Andrieu, «Transição digital na construção civil: analisar a atividade de 'levantamento de inconformidades' mediada por um aplicativo informático de uma diretora de obra », Laboreal [Online], Volume 14 №2 | 2018, posto online no dia 01 dezembro 2018, consultado o 09 outubro 2019. URL : http://journals.openedition.org/laboreal/629 ; DOl : 10.4000/laboreal.629

Este documento foi criado de forma automática no dia 9 outubro 2019

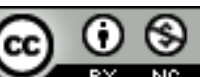

Laboreal está licenciado com uma Licença Creative Commons - Atribuição-NãoComercial 4.0 Internacional. 


\section{Transição digital na construção civil: analisar a atividade de} 'levantamento de inconformidades' mediada por um aplicativo informático de uma diretora de obra

Transición digital en el sector de la construcción: analizar la actividad del 'levantamiento de reservas' mediada por una aplicación informática de una directora de obra

Transition numérique dans le bâtiment: analyser l'activité de 'levée de réserves' médiatisée par une application métier d'une conductrice de travaux

Digital transition in the building industry: to analyze the construction site manager's activity of 'lifting of reservations' mediated by a business application

Elodie Chambonnière, Jacqueline Vacherand-Revel e Bruno Andrieu Tradução : Laura Camara Lima

\section{NOTA DO EDITOR}

http://dx.doi.org/10.15667/laborealxiv218ec

Manuscrito recebido em: julho/2018

Aceite após peritagem: novembro/2018

\section{Introdução: contexto e problemática}

O setor de construção está claramente a entrar na transição digital: o desafio, do que se apresenta como sendo uma revolução cultural, é o de conseguir passar da era do papel à 
digitalização plena. No que se refere à função de diretor de obra, a digitalização é um duplo desafio, pois pressupõe que uma cultura ancorada preferencialmente em trocas orais, frequentemente presenciais passe por uma transformação radical. Tornou-se vital para a sobrevivência dos grandes grupos multinacionais do setor que eles sejam bem-sucedidos em operar essa transição para a digitalização plena. Ela é igualmente estratégica porque potencia o acesso a e novas candidaturas em mercados hiperconcorrenciais dentro de um setor em fraco crescimento. É através de muita agilidade que se podem desenvolver capacidades distintivas sustentáveis em relação à concorrência (Vacherand-Revel, 2017a).

2 Com o objetivo de entender as motivações e os recursos de tal inovação, da rutura cultural relativa às práticas coletivas e das incidências organizacionais e humanas dessa transição digital, realizamos uma pesquisa doutoral em colaboração com uma empresa especializada em reabilitação, que faz parte de um Grupo multinacional de construção, que se posiciona entre os dez primeiros grupos do mundo no setor da construção civil e obras públicas.

O objetivo consiste em experimentar novas práticas colaborativas, mediadas por diversos dispositivos digitais, entre os diferentes parceiros envolvidos em todas as etapas de um projeto. O principal operador dessa transição digital é a utilização de um método colaborativo (denominado BIM [1]) em torno de uma maquete numérica virtual compartilhada. Essa última é o principal eixo de experimentação para o Grupo (supracitado) que espera poder empregá-la em diferentes empresas, em escala nacional.

Por essa razão, a tese atende a uma dupla expectativa. A primeira está ligada à compreensão da complexidade das práticas atuais das equipes de projeto de uma obra e à maneira pela qual elas estão sujeitas a uma reconfiguração graças à mediação das atividades. A segunda, no âmbito da investigação-ação, é de acompanhar essa transição digital, mantendo o contacto com os atores-chave do projeto de reabilitação em uma obra piloto. Sobre as bases dos conhecimentos adquiridos, pretendemos assim desenvolver a 'capacidade de agir' (Clot, 2008) e de 'interagir' dos atores, no contexto de colaboração mediatizada (Vacherand-Revel, 2015, 2017b).

Guiadas por essas expectativas, as nossas investigações no terreno são realizadas em situação real de trabalho, em dois estaleiros de uma empresa francesa de reabilitação. 0 primeiro, 'tradicional', dispõe de ferramentas numéricas clássicas (e.g. para a realização e edição de projetos) mas no qual introduzimos, a título experimental, um Tablet, equipado de um aplicativo especializado. Um segundo, que está-se iniciando, é inteiramente digitalizado com a utilização piloto da maquete. A vontade do Grupo é de inserir a maquete digital no Tablet.

6 Esse artigo refere-se ao primeiro estaleiro que tem como finalidade a realização de uma centena de habitações. Dentre os inúmeros atores que participaram da realização dessa obra, optamos por investigar as práticas existentes e recentemente digitalizadas de um ator chave da obra: o diretor de obra. Esse último foi recentemente equipado com um tablet portátil, utilizou, pela primeira vez, um aplicativo especializado para efetuar a atividade de 'levantamento de inconformidades'. As inconformidades dizem respeito aos defeitos de realização que foram repertoriados no final da obra. Elas devem ser anotadas para serem retomadas pelos trabalhadores, segundo as indicações do diretor de obra. Uma vez resolvidas as disfunções, é necessário fazer uma constatação ao empreiteiro [2] para tornar esse levantamento efetivo e permitir a receção da obra. 
7 Com o intuito de compreender mais precisamente a incidência do aplicativo sobre a atividade de 'levantamento de inconformidades' do diretor de obra, é necessário situar essa atividade no contexto do estaleiro no qual ela se realiza e o que a caracteriza.

\section{A vida do estaleiro em todos os seus estados}

8 A vida no estaleiro insere-se num sistema complexo, sempre em movimento (1.1). 0 diretor de obra é um verdadeiro chefe de orquestra (1.2), uma de suas inúmeras missões é assegurar a entrega da obra com 'zero defeitos' (1.3).

\subsection{0 estaleiro em ação: complexidade e dinâmica}

9 No plano organizacional, um estaleiro estrutura-se em quatro fases: a resposta ao concurso, a preparação do estaleiro, a realização dos trabalhos, e o encerramento. As fases são delimitadas no tempo. Inicialmente, podemos pensar que elas são todas compartimentadas, mas a realidade é outra. Por exemplo, se um estaleiro é mal preparado, a realização da obra será difícil e o encerramento poderá ser retardado. A atividade de 'levantamento de inconformidades' marca o fim da realização dos trabalhos, e, por consequência, o encerramento do estaleiro porque o imóvel pode ser recebido e entregue ao cliente.

10 Em cada uma dessas fases, cada tarefa é independente das outras (Six, 2016). As tarefas devem ser sequenciais. Assim, é preciso começar por instalar a rede subterrânea antes de cimentar, por exemplo. Por questões de segurança, mas também de fluidez da progressão da obra, os operários recebem prescrições para adotarem modos operatórios específicos para não atrapalharem a atividade uns dos outros. Quando se compartilha um mesmo local de trabalho, torna-se necessário uma articulação com o trabalho do outro, em tempo real ou em tempo diferido. Por exemplo, em situação, numa mesma divisória, o canalizador instala a rede de canalizações enquanto o pintor pinta as paredes. Em tempo diferido, por exemplo, para que o colocador de pranchas no solo possa fazer a colocação do piso, é preciso que o solo tenha sido aplanado e preparado pelos pedreiros. Na falta desta preparação pelos pedreiros a atividade do instalador de pranchas fica impedida.

11 A vida de um estaleiro é sempre móvel na sua configuração (Doniol-Shaw, 1997; Guffond \& Leconte, 2001). Ela também é marcada pela incessante ocorrência de acontecimentos inesperados (fugas de água, pintura que descasca, acidentes mais ou menos graves...). O meio ambiente de trabalho no qual o diretor de obra evolui é complexo pois cabe a ele a gestão quotidiana dos imprevistos. Vejamos agora como esse ator conduz o seu estaleiro.

\subsection{Conduzir um estaleiro: uma atividade de chefe de orquestra}

12 Para poder realizar diversas atividades [3], o diretor de obra socorre-se de uma rede envolvendo um grande número de atores: cliente, empreiteiro, arquiteto, técnico de segurança, empresas subcontratadas, operários, serviços funcionais (e.g. entrega de produtos), fornecedores e suas empresas (e.g. dirigentes). A diversidade de interlocutores obriga o diretor de obra a adaptar-se, em permanência, aos diversos 'mundos sociais' em presença (Schutz, 1987). Nesses mundos socioprofissionais forjam- 
se linguagens de ação e 'visões profissionais' (Goodwin \& Goodwin, 1996; Béguin, 2004) que não são necessariamente convergentes, na maneira de dizer, de descrever, de compreender os eventos e de perceber uma situação. O que está em jogo e as visões diferem de acordo com a posição dos atores na hierarquia do estaleiro (VacherandRevel, 2003). Diretor de obra é um 'ator' (nos termos de Goffman $(1959,1971))$ que assumirá um 'papel' diferente em função das 'cenas'. Ele não se dirigirá ao diretor da mesma maneira que fará em relação ao operário.

Verdadeiro chefe de orquestra, com múltiplas missões operacionais, o diretor de produção, entre outras missões, de enquadrar, de prescrever e de coordenar o trabalho de um grande número de trabalhadores de diferentes profissões da construção civil, que co-atuam no estaleiro (Forrierre \& Six, 2010). O conjunto dos trabalhadores designam 'a entidade organizacional de produção propriamente dita' (Cru, 2016, p.115).

O diretor de obra é igualmente responsável pela segurança do estaleiro e pela qualidade dos trabalhos efetuados. 0 objetivo é de entregar o imóvel nos prazos determinados contratualmente com o cliente. Caso contrário, as penalizações relativas ao atraso podem ser cobradas, o cliente pode ficar insatisfeito, e isso poderia ter repercussões na obtenção de futuras encomendas. A tradução operacional desse objetivo de qualidade incorpora-se de maneira exemplar na atividade essencial dita de 'levantamento de inconformidades'.

\subsection{A atividade de 'levantamento de inconformidades'}

Um estaleiro é entregue ao cliente quando não há inconformidades. Relembrando, as inconformidades são todos os defeitos que foram repertoriados. No fim da obra, o diretor de obra efetua as OPR (Operações Prévias à Receção). Quando ocorre esse tipo de visita, se houver inconformidades, ele anota para que sejam recuperadas. Antes das OPR, o diretor de obra efetua preventivamente inspeções regulares aos estaleiros para identificar os defeitos e 'elimina-los', a fim de reduzi-los ao mínimo possível. Depois das OPR, o diretor de obra efetua inspeções ao estaleiro para verificar que os defeitos (reportados ao empreiteiro) foram adequadamente reparados pelos trabalhadores, podendo, assim, ser 'levantados'. Enfim, para efetivar esse 'levantamento' e permitir a entrega da obra, é preciso que o diretor de obra faça essa constatação (operação de receção).

16 Para alcançar o objetivo de qualidade do 'defeito zero', o diretor de obra realiza e sobretudo atualiza uma planificação que orienta as suas ações (Duc, 2002). Desde o início do estaleiro, uma das prescrições do diretor de obra consiste em tudo fazer para que o planeamento seja concretizado e que a obra seja realizada de acordo com a vontade do cliente, sem deixar de lado a segurança dos trabalhadores. A gestão do estaleiro assemelha-se a um trabalho de projeto, pois se o planeamento fornece um quadro de ações em pano de fundo, já se sabe que esse planeamento será sem dúvida perturbado. De fato, a realização de obras geralmente atrasa, em resultado de imprevistos constitutivos de um estaleiro. Assim, ele tem por missão antecipar, e de definir um tempo aproximativo para fazer face à resolução de imprevistos.

Pareceu-nos pertinente escolher como objeto de estudo a atividade de 'levantamento de inconformidades' porque, de acordo com as afirmações dos diretores de obra da empresa de reabilitação, recolhidos durante nossas observações, 'ela está longe de ser simplesmente uma atividade de fim de obra, pois determina em grande parte o 
desenrolar e a gestão do estaleiro, orientando fortemente as ações que nele se desenvolvem'. Essa é então uma das atividades essenciais do diretor de obra que marca o fim da obra e faz parte de uma avaliação do trabalho da equipa. Ela garante a satisfação do cliente quando a obra está terminada e é rececionada sem nenhum defeito a ser reparado.

o ângulo de análise que propomos concentra-se no ponto de vista do diretor de obra, sem, por isso, deixar de considerar a configuração colaborativa da ação que a sustenta. Ao mesmo tempo, investigamos a função específica dessa nova mediação e as transformações que ela provoca na atividade de 'levantamento de inconformidades' diretor de obra.

Retemo-nos inicialmente sobre uma proposição teórica de articulação entre as dimensões situadas e incorporadas da atividade, por um lado, e seu desenvolvimento histórico-cultural, por outro lado, a fim de compreender a complexidade desse objeto de estudo. Depois esclarecemos a abordagem empírica de natureza etnográfica que nos permite investigar o trabalho no estaleiro argumentando em relação ao interesse de penetrar nos seus bastidores. Enfim, com a dupla expectativa que constitui globalmente nossa linha analítica, nós apresentamos os principais resultados dessa investigação. Eles contribuirão para esclarecer o trabalho no estaleiro por intermédio da atividade de 'levantamento de inconformidades' do diretor de obra. Eles interrogam o papel e a experiência singular do diretor de obra na fábrica do estaleiro. Eles analisam a maneira como os artefactos se inserem na atividade de 'levantamento de inconformidades', os recursos que oferecem e as restrições que impõem às interações colaborativas.

\section{Apreender a atividade de 'levantamento de inconformidades': enquadramento teórico}

Captar a amplitude das mudanças previsíveis dessa transição digital para o trabalho dos atores, e a atividade de um diretor de obra, em particular, necessita confronta-lo com os diferentes níveis de complexidade e à sua dinâmica específica ao longo da duração da obra. Apreende-los supõe dotar-se de quadros teóricos capazes de considerar, sem isolar a priori na análise, os elementos organizacionais e situacionais suscetíveis de esclarecer a função específica da mediação digital para a atividade. Para atender a essa ambição, somente uma abordagem sistémica nos parece pertinente. Nessa perspetiva, propomos uma articulação teórica entre as dimensões situadas e incorporadas da atividade e seu desenvolvimento histórico-cultural, que já foi testada em outros contextos de pesquisa (Vacherand-Revel, 1995, 2015; Ianeva, 2013; Ianeva \& VacherandRevel, 2015; Ianeva, Vacherand-Revel \& Licoppe, 2017). Esta articulação refere-se às Teorias da Ação, por um lado, e às Teorias da Atividade, por outro lado. Ela pretende compreender o trabalho mediado tal como ele é realizado, em situação, tal como ele se vive, se experimenta e se desenvolve nas suas modalidades concretas de realização da atividade e das diversas mediações digitais.

21 As Teorias da Ação são principalmente ancoradas nos paradigmas interacionistas e situacionistas, (e.g. obra de Goffman, 1959, 1971; Lave, 1988; Goodwin \& Goodwin, 1996; Grosjean \& Lacoste, 1999; Suchman, 2007). Destacamos para esse trabalho, que os situacionistas tematizam o caráter indeterminado da ação, sublinhando a sua natureza emergente na dinâmica das interações e contingente, pois ela depende das 
particularidades ligadas a uma determinada situação. De acordo com Lave (1988), distinguiremos duas fases em uma situação (arena e setting) para caracterizar a relação dialética que reúne a tarefa, o indivíduo e o meio ambiente. Assim, a arena é antes de mais nada o ambiente social objetivo representado pela situação do estaleiro como um dado persistente estendendo a atividade do diretor de obra. Compõe-se de uma multiplicidade de atores que pertencem a variados corpos de ofício (pedreiro, canalizador, eletricista...) com diferentes níveis de qualificação, de competências e de experiências e que devem ser coordenados e orquestrados pelo diretor de obra. Assim, o estaleiro caracteriza-se pela coatividade e multiplicidade de ofícios dos trabalhadores. A arena revela também o meio ambiente espaciotemporal do estaleiro. Caracteriza por múltiplos lugares de ação, no interior e no exterior. Nesse último caso, ele está submetido ao calor, ao frio ou às intempéries. Mesmo se a duração da obra está contratada, a sua duração raramente corresponde ao que tinha sido previsto e tende a extravasar. Se abordamos agora a situação do ponto de vista do setting, interessamo-nos então por essa parte do meio ambiente marcada pela ação dos atores do estaleiro. Nessa perspetiva de análise podemos considerar que os diversos estados da obra são frutos da coatividade dos diversos corpos profissionais. A progressão deles está sujeita às cadências das diferentes tarefas a serem efetuadas, à quantidade de trabalho realizado e à coordenação de tudo que deve ser assumida pelo diretor de obra. Assim, retemos das abordagens interacionistas, a necessidade de levar em conta o conjunto das modalidades utilizadas para comunicar no estaleiro, face a face ou à distância: modalidades verbais, corporais, non verbais, faladas ou escritas. Uma atenção particular é atribuída à utilização dos artefactos e à maneira pela qual tomam parte e se integram na atividade de 'levantamento de inconformidades' contextualizada ao seio dos diversos lugares e tempos de ação de um estaleiro.

As Teorias da Atividade são ancoradas no paradigma construtivista e inspiradas na psicologia histórico-cultural russa (Vygotski, Leontiev) que se desenvolveu baseada na ideia de uma codeterminação do social e do psíquico. Elas se expandiram no âmbito do trabalho, nomeadamente, graças aos pesquisadores escandinavos (e.g. a obra de Engeström, 1987) e franceses na clínica da atividade (e.g. Clot, 1999, 2008).

De acordo com essa orientação, a atividade não diz respeito a uma entidade circunscrita em um espaço-tempo definido, nem a um grupo de pessoas ou ainda a uma organização. Os contornos, os limites e a estrutura da atividade são definidos pelo seu objeto. De acordo com Engeström (1987), o que distingue os sistemas de atividade, uns dos outros, são as suas finalidades. Toda atividade é dirigida, quer dizer, orientada por um objeto. Esse último refere-se às preocupações compartilhadas pelo coletivo, por um lado, e a uma trajetória orientada na direção do produto da atividade, por outro lado. Apresentase principalmente como um horizonte de possibilidades compartilhado pelos profissionais que se atualiza ou se desdobra ao longo do trabalho (Ianeva \& VacherandRevel, 2015). Como indica a estrutura de um sistema de atividade (cf. Figura 1), o sujeito reenvia para o diretor de obra, cujo ponto-de-vista foi escolhido para análise. Entretanto, a atividade é sempre coletiva na medida em que ela implica a intervenção coordenada de um conjunto de atores do mundo da construção civil, formando uma comunidade por meio de uma infraestrutura de mediação sociotécnica (divisão do trabalho, regras, normas, instrumentos), ela mesma portadora de uma definição social da orientação produtiva que constitui seu objeto. 
Figura 1: Estrutura de atividade de Engeström.

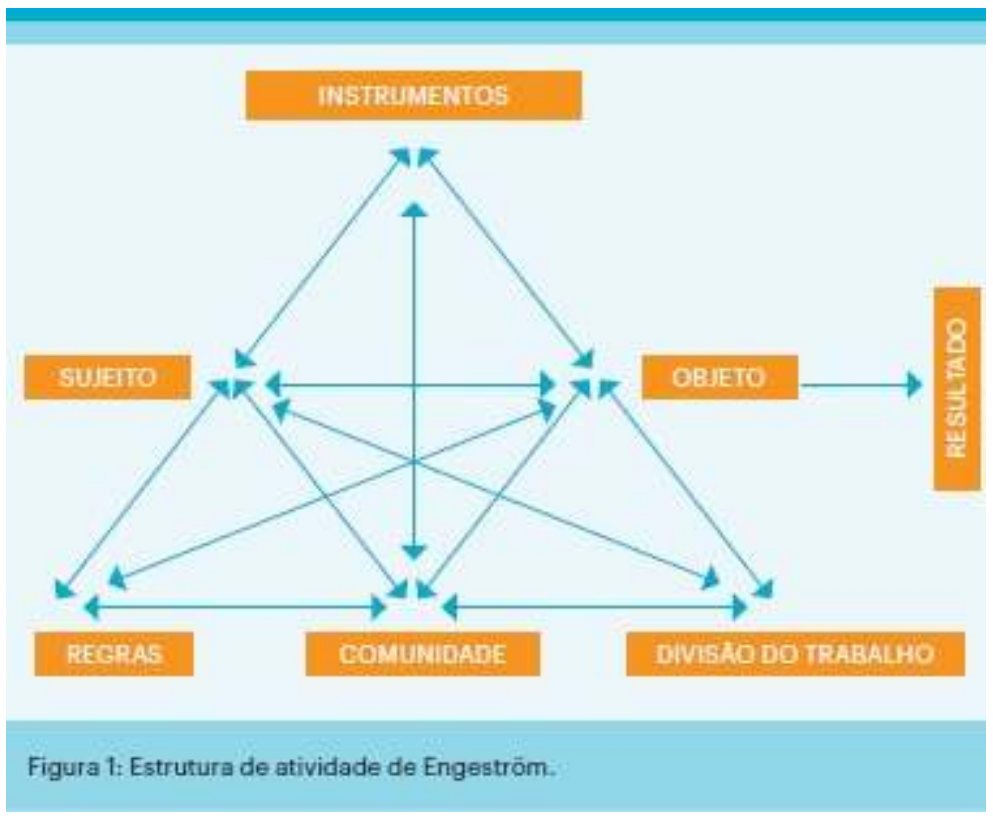

O que nos interessa na situação de estaleiro é o que Clot, (1999) designa por 'real da atividade'. Na situação vivida, a atividade é 'triplamente dirigida: pela conduta do sujeito, dirigida através do objeto da tarefa, e ela é também dirigida em direção aos outros' (Clot, 1999, p. 98). O real da atividade integra também à ação visível um horizonte de potencialidades múltiplas fornecendo os recursos coletivos para agir coletivamente ou, ao contrário, os motivos de impedimento ao desorganizá-la. Também, 'as atividades suspensas, contrariadas, ou impedidas, ou seja as contraatividades, devem ser admitidas na análise' (Clot, 2008, p. 89).

A articulação teórica que propomos permite assim de apreender a atividade de 'levantamento de inconformidades' do diretor de obra em toda sua espessura. Ela será observada, ao mesmo tempo, nos locais de interações multimodais autênticas que a realizam, com seus planos de fundo contextuais, na maneira pela qual os artefactos se ancoram nessa atividade e na perspetiva de seu desenvolvimento e de seus impedimentos. Sobre essas dimensões, a apreensão da inteligibilidade da atividade de 'levantamento de inconformidades' não pode prescindir da compreensão da organização, de sua construção histórico-cultural. As práticas profissionais são baseadas numa relação com os objetos técnicos e com os hábitos culturalmente ancorados, como pode ser, por exemplo, a utilização da planta visível em lugares estratégicos do estaleiro, de suas modificações à lápis ou de suas diferentes leituras em função das profissões in situ. Esses elementos ultrapassam amplamente a localização das interações em situação, pois eles englobam-na e dão-lhe todo o seu sentido. Assim, o estudo sistemático das modalidades de colaboração e de coordenação do diretor de obra com os atores do estaleiro aparece como um ponto privilegiado de observação para apreender o potencial de desenvolvimento da atividade considerada.

Com essa perspetiva de análise, é preciso observar o modo como se constrói a complexidade da situação do estaleiro com a pluralidade de seus atores e de seus lugares de ação no período temporal que produz a dinâmica e o sentido da ação. Interrogaremos, igualmente, o modo pelo qual a passagem do papel à era digital (pela via da inserção e das primeiras utilizações do aplicativo profissional estudado) é 
suscetível de reorientar a atividade de 'levantamento de inconformidades' e os tipos de relação ao outro no que autoriza, facilita, constrange ou impede.

Em coerência com esse enquadramento teórico, a abordagem etnográfica, exposta na próxima parte, procede com a mesma intenção de observar in situ o trabalho vivo do estaleiro na sua globalidade e localidade.

\section{Etnografia da atividade num estaleiro}

Primeiramente, queríamos fazer jus à complexidade do estaleiro com seus jogos de escalas espácio-temporais de ação e de interação. Em seguida, apreender, experimentando 'do interior', a riqueza, os desafios e os fenómenos vitais que nutrem a atividade investigada. Adotamos, para esse efeito, várias posturas etnográficas (3.1 e 3.2.), e construímos uma gama de instrumentos de pesquisa (3.3).

\subsection{Imersão na cena e nos bastidores do estaleiro}

29 Numa perspetiva de investigação-ação, pesquisar etnograficamente um setor tão complexo como a construção civil, sobretudo quando este nos é totalmente estranho, é uma prova difícil para o investigador. Isso solicita tempo, engajamento, e uma compreensão mínima prévia, da organização, dos eventos e das restrições de um estaleiro. Essas são as condições necessárias para ser aceite na qualidade de investigador, ganhar a confiança dos atores e construir o que se tornará o 'nosso campo' de pesquisa. É também o que garante a validade ecológica dos dados obtidos, ponto essencial para apreender as práticas não 'ideais', mais efetivas nas condições autênticas de sua realização.

Um primeiro período de familiarização com o campo, que se estendeu durante cinco semanas, colocou-nos em capacidade de ver, de identificar, o que será oportuno de observar e de enquadrar. Esse período esteve articulado em torno de leituras de trabalhos na área, a fim de compreender o contexto (cf. Parte 1) e de entrevistas exploratórias informais com o diretor de obra. $\mathrm{O}$ que esse último expressou coincidiu com o que encontramos em nossas leituras: os estaleiros são geralmente marcados pela urgência, a gestão de imponderáveis, de eventos de todo tipo e que o diretor de obra é a pessoa chave, que faz a função de chefe de orquestra do estaleiro. Assim percebemos a necessidade de dedicar uma atenção particular a esses elementos.

31 Ao fim desse período, era necessário entrar verdadeiramente na 'cena da representação' e obter um acesso privilegiado aos 'bastidores' (no sentido dramatúrgico definido por Goffman, 1959, 1971), do estaleiro francês de reabilitação, no qual foi introduzido, a título experimental, um tablet dispondo de somente um aplicativo profissional. A aspiração da empresa é que esse tablet, com seu aplicativo dedicado ao 'levantamento de inconformidades', seja utilizado, no final, por todos os diretores de obra, no conjunto de todos os estaleiros. Esclareçamos que no momento de nossa pesquisa, a empresa de reabilitação estava no início de sua passagem ao estaleiro totalmente digitalizado.

Para um cliente construtor de habitações sociais, os trabalhos consistiam em transformar um antigo imóvel numa residência social de 108 apartamentos. Durante toda a duração dos trabalhos, que se estendeu por seis meses, à razão de dois dias de 
presença contínua, nós vivemos em imersão no campo, no coração da vida desse estaleiro. A análise da atividade de 'levantamento de inconformidades' só podia considerar-se pertinente se ela se inscrevesse numa temporalidade significativa do ponto de vista do estaleiro considerado. Foi à custa dessa imersão prolongada, favorecendo uma aculturação e uma socialização com as práticas, que nos tornamos capazes de interrogar, de observar e de analisar o trabalho que se efetuava. Foi-nos assim oferecida a possibilidade de compreender a linguagem, o vocabulário especializado das profissões e os implícitos compartilhados pelos atores. Tivemos também que nos familiarizar com as regras de segurança, nomeadamente o uso de equipamentos de proteção individual: sapatos e capacete de segurança. Sem essa presença 'equipada' no estaleiro e a confiança tecida com os atores, certos fenómenos observados teriam sido incompreensíveis, outros teriam permanecido 'invisíveis' (Star \& Strauss, 1999) para um observador exterior. Por exemplo, teria sido impossível de ter acesso aos aspetos críticos do trabalho, àqueles que preferimos esconder, aos pequenos arranjos locais com as regras prescritas da profissão, às práticas difíceis demais tecnicamente para expor a alguém e mesmo a dados confidenciais. Enfim, não teríamos tido acesso aos eventos imprevisíveis e às práticas exotéricas do estaleiro. 0 verdadeiro desafio dessa abordagem situa-se em torno do being there (Rouleau, 2013) [4]. Pois, como já sublinhava Malinowski, em 1922 (citado por Vilette, 2014) 'geralmente as pessoas não fazem o que eles dizem que fazem, mas outra coisa. Por essa razão, é preciso estar presente para ver o que elas fazem'.

Mobilizados por esses princípios e convicções, fizemos a escolha de seguir os passos do diretor de obra, em situação, em todos os seus deslocamentos e 'estar lá', como uma sombra, ser a testemunha privilegiada das suas interações com o conjunto de atores implicados no projeto. Essa prática específica da etnografia organizacional é nomeada 'shadowing' (Grosjean \& Groleau, 2013).

34 O diretor de obra de nossa pesquisa é uma mulher. Ela é engenheira de formação, tem 24 anos e está no cargo faz um ano. Durante a duração da obra, ela teve sob sua responsabilidade a coordenação do trabalho de 21 empresas subcontratadas [5]. Os períodos de coatividade entre subcontratados estão sempre presentes ao longo da realização dos trabalhos. No máximo, uma dezena de empresas, sendo 35 trabalhadores, podiam intervir em situação de coatividade e isso durante um ou dois meses, principalmente no final da obra. Efetivamente, a recuperação de defeitos e os últimos acabamentos necessitam de mobilizar o maior número de trabalhadores. Além disso, 15 profissionais provenientes de profissões diferentes (cliente, empreiteiro, técnico de segurança...) atuaram no estaleiro.

\subsection{Observação participante}

Ao longo dessa imersão no estaleiro, a primeira postura etnográfica adotada, com a qual estávamos claramente identificados como pesquisadores por certos atores institucionais, revelou-se dificilmente sustentável. Com efeito, devido às particularidades do estaleiro, onde é preciso agir rapidamente num tempo restrito, fomos solicitados enquanto pessoa recurso para participar de algumas tarefas e reconhecidos como interlocutores credíveis em situação. Ao longo do tempo, uma real confiança foi-nos assim acordada. Investidos dessa prática de membro (no sentido de Garfinkel, 1987) quer dizer, com competências reconhecidas pelos atores envolvidos no estaleiro, a postura etnográfica evoluiu naturalmente para tomar a forma de uma 
observação participante no estaleiro em paralelo com a observação em 'shadowing' da diretora de obras. Participando dessa atividade, socializamo-nos e familiarizamo-nos mais e compreendemos melhor algumas das atividades da diretora de obra. Por exemplo, nós ajudamos na arrumação do material e no descarregamento das entregas.

Demos mesmo a nossa contribuição na atividade de 'levantamento de inconformidades'. No momento das OPR com o empreiteiro, a diretora de obra esteve ausente para resolver um problema importante. Assim, ela não conseguiu ficar com o empreiteiro para anotar os defeitos que ele reportava. Considerando que era necessário desempenhar somente um papel de 'escrivão', propusemos a nossa ajuda, a fim de substituir momentaneamente a diretora de obras. Como não sabíamos utilizar a aplicação técnica, tomamos notas no nosso telefone celular, especificando o que deveria ser reparado em cada apartamento. Em seguida, transmitimos nossas notas, de viva voz, aos trabalhadores que deviam reparar os trabalhos.

\subsection{0 conjunto de instrumento de recolha de dados}

37 As duas posturas etnográficas que praticamos inscrevem-se na linha de Becker (2000). Contrariamente a um trabalho experimental, não se trata de produzir dados solicitando aos atores que façam alguma coisa específica de nosso interesse, mas de esperar que se produzam eventos que tenham importância para eles. Com essa postura, concebemos um conjunto de instrumentos ad hoc tendo em conta a vida do estaleiro. Privilegiamos, de início, observações abertas para compreender a função do diretor de obra e depois observações mais dirigidas para certas atividades. Em alguns momentos da vida do estaleiro foram filmados com uma câmara GoPro posicionada em arnês, que permite de fixa-la no nosso peito. Dispondo assim de liberdade de movimentos, pudemos participar das atividades e tomar notas mais facilmente.

O objetivo consistia em observar em detalhe a atividade tal como ela se realiza da maneira pela qual ela se realiza (modos operatórios, raciocínios e estratégias de ação adotadas pela diretora de obra). Ao longo dessas observações, recolhemos diferentes tipos de verbalizações que foram úteis para compreender, explicitar as ações da diretora de obra, apreender o que a motivava, para confronta-la com o que ela estava a realizar. As verbalizações recolhidas são de naturezas diferentes. Trata-se o mais frequentemente de verbalizações espontâneas. Com efeito, a diretora de obra praticava bastante o solilóquio, ela tinha a tendência a comentar com ela mesma o que estava fazendo. Notemos que essas verbalizações poderiam ser-nos diretamente endereçadas, mais era mais raro. Por vezes, e somente se necessário, de modo a não perturbar ou correr o risco de interromper o curso de seu trabalho, nós a convidávamos a verbalizar o que ela estava a realizar. Recolhemos também interações verbais e não-verbais através dos nossos registros audiovisuais.

39 No total, o corpus de dados obtidos compreende: i) notas etnográficas (trocas informais, escritos, esquemas, citação dos atores) resultantes do diário quotidiano de acompanhamento do estaleiro; ii) as transcrições das gravações audiovisuais, reforçadas por fotografias. É sobre essa base que construímos nossas análises e chegamos ao resultado que apresentamos na próxima parte.

Os materiais desse corpus de dados fizeram objeto de análises temáticas (inventariar os temas abordados ao longo dos dias no estaleiro, durante as reuniões...) e visuais (momentos-chave na realização das tarefas) depois efetuadas as modelizações dos 
sistemas da atividade de 'levantamento de inconformidades'. Atribuímos uma importância particular a certas observações, como o número e as modalidades de interações da diretora de obra com seus interlocutores (tipos, informações transmitidas...), as deslocações no estaleiro, os apoios mobilizados e sua modalidade de utilização. Num primeiro tempo, em proximidade de ação, as análises foram coconstruídas com a diretora de obra. De seguida, elas foram retrabalhadas com os atores-chave do estaleiro: a diretora de obra, o diretor geral da obra, o diretor de produção e um dirigente de uma empresa subcontratada de canalização.

\section{Análise e resultados}

Quer seja antes ou depois das OPR, a diretora de obra executa a inspeção do estaleiro sozinha ou em binômio com sua $\mathrm{n}+1$ (diretora geral da obra). Devido aos ritmos acelerados dos eventos que marcam então o estaleiro, essas inspeções são realizadas várias vezes para identificar os defeitos e depois para verificar que esses últimos foram reparados à medida da evolução da obra. A atividade de 'levantamento de inconformidades' não pode ser efetuada em paralelo com uma outra atividade pois a diretora de obra é mobilizada no estaleiro unicamente a esse efeito. O dia das OPR, a diretora de obra, e por vezes o diretor geral da obra, acompanha a diretora de obra. Como esse último representa o cliente, sendo o único, no momento dessas visitas, que fica encarregado de assinalar as inconformidades. Por vezes, uma negociação inicia-se entre esses atores para não inscrever os defeitos. Seja porque eles são muito 'pequenos', seja porque eles podem ser reparados imediatamente.

Para atingir o objetivo de qualidade de 'defeito zero', a diretora de obra supervisiona entre outros, os trabalhos realizados pelos trabalhadores. Isto pressupõe muitas trocas e numerosas ações a fim que a realização da obra decorra da melhor maneira possível. Essas trocas acontecem sob formas diretas, presencialmente ou mediadas pelos artefactos. Assim, nesta parte vamos estudar como a diretora de obra atua, em situação, tomando como medida os artefactos (4.1). Isso nos permitirá compreender as transformações induzidas pela aplicação técnica na atividade de 'levantamento de inconformidades' (4.2).

\subsection{Os artefactos mobilizados na atividade de 'levantamento de inconformidades'}

Sublinhamos que o uso de artefactos mobilizados no quadro da atividade de 'levantamento de inconformidades' pode também sê-lo no contexto de outras atividades da diretora de obra.

\subsubsection{As vicissitudes das plantas no suporte papel}

A diretora de obra usa frequentemente a planta papel para transmitir as diretivas. Ela é marcada para indicar onde os trabalhadores devem intervir: por exemplo, a diretora de obra tinha assinalado com a cor verde os radiadores cujo funcionamento tinha que ser controlado pelos trabalhadores (cf. Figure 2). Para isso, estes últimos tinham que manipular os materiais, a planta em papel é assim facilmente transportável e deixa as mãos livres. 
Figura 2: Um extrato de uma planta em papel.

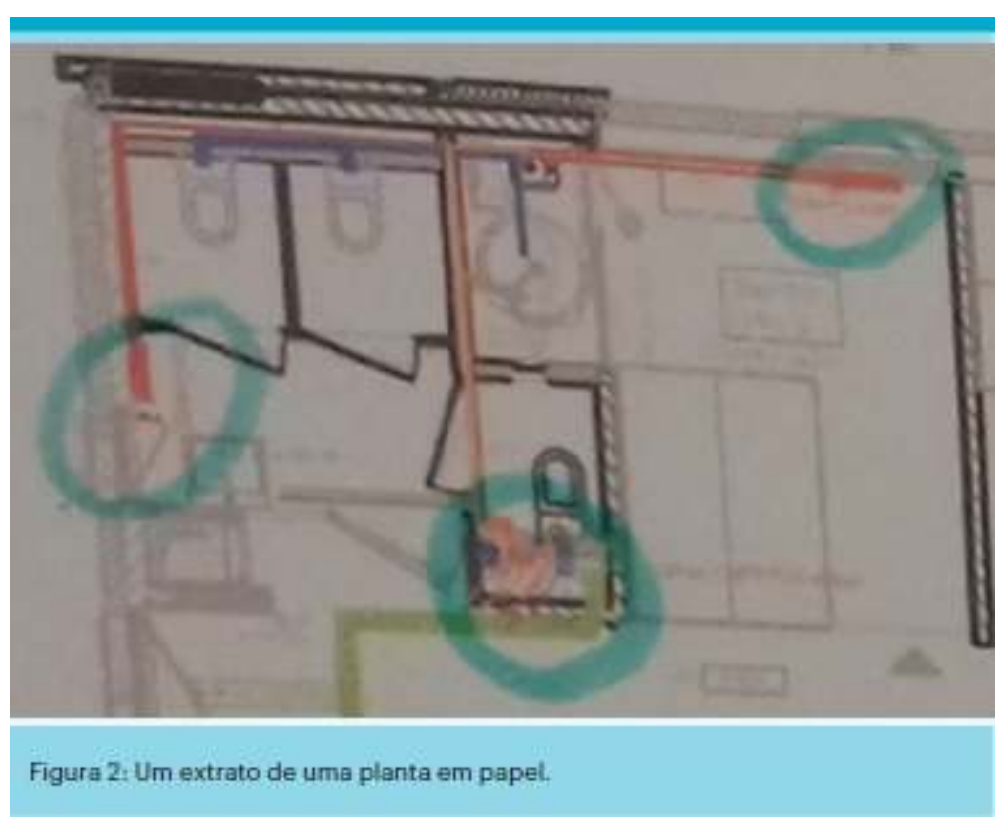

A planta em papel serve igualmente de ajuda para se localizar no espaço do estaleiro; com a finalidade de que os trabalhadores não se enganem, por exemplo para colocar as instalações no local adequado (e assim atingir o 'zero defeito'), as plantas em papel são expostas no imóvel a ser reabilitado. Para informação, a utilização do digital apoia há muito tempo a atividade, uma vez que as plantas em papel são realizadas com a ajuda de um programa específico e depois imprimidas.

Certos usos da planta em papel apresentam, ainda sim alguns inconvenientes. 0 risco é que as informações das plantas em papel se degradem por conta de respingos de pintura ou de poeira que se acumulam ou que as informações pertinentes desapareçam, se tornem ilegíveis na sequência de informações acrescidas. As plantas em papel podem também perder-se voando com o vento. Além disso, as informações dadas pela planta são frequentemente consideradas diminutas. As nossas observações revelaram que alguns trabalhadores não têm a competência profissional para ler uma planta, nem podem decodificar as informações (a que correspondem uma cor e uma dimensão inscrita?), ainda menos associa-las a espaços para se localizar no estaleiro; alguns ainda não dominam muito bem a língua francesa, as anotações escritas explicando um detalhe não constituem então nenhuma ajuda. Consequentemente, eles não efetuam ou efetuam mal as suas tarefas. Nós veremos que o tablet portátil, por via das fotografias do aplicativo que são diretamente associadas aos lugares onde é preciso intervir, é uma alternativa para quando os trabalhadores têm dificuldade de se localizar no espaço, por exemplo.

\subsubsection{O telefone celular. artefacto indispensável para comunicar}

Um outro artefacto testado que a diretora de obra emprega muitas vezes é o telefone celular (Forrierre \& Six, 2010) com sua função de chamada e de fotografia. Ele permitelhe coordenar e de regular a atividade no estaleiro para almejar o 'defeito zero'. 
A diretora de obra possui um escritório no estaleiro, nomeado 'escritório'. Quando os trabalhadores não vêm ao escritório, ela entra em contato com eles por telefone. 0 telefone celular permite igualmente à diretora de obra de estar em contato permanente com a rede de atores. Em média, por dia, ela recebe e emite quarenta ligações. A chamada, quer seja emitida ou recebida, produz uma fragmentação e uma dispersão significativa da atividade (Datchary, 2011).

No estaleiro, para preparar as OPR, a utilização da fotografia é muito usada, ela poderia assemelhar-se a uma catacrese (Clot \& Gori, 2003). De acordo com Rabardel (1995), a diretora de obra apropriou-se do instrumento 'telefone celular' (processo de génese instrumental). As fotografias não são nunca imprimidas, elas são transmitidas por email às pessoas envolvidas ou mostradas presencialmente, no estaleiro ou no 'escritório', no telefone celular da diretora de obra.

Em nossas observações, identificamos que a diretora de obra envia as fotografias por email para deixar um 'rastro' escrito. Esta rastreabilidade assegura, concretamente uma função mnemónica de lembrança, para os trabalhadores sobre aquilo que devem fazer. Assim, a diretora de obra tira fotos para indicar aos trabalhadores onde eles devem intervir para reparar o defeito e/ou que eles devem fazer para evitar as inconformidades. Por exemplo, ela é usada para terminar corretamente a preparação das paredes (cf. Figure 3), ou ainda para efetuar advertências.

Figura 3: A necessidade de ter paredes lisas

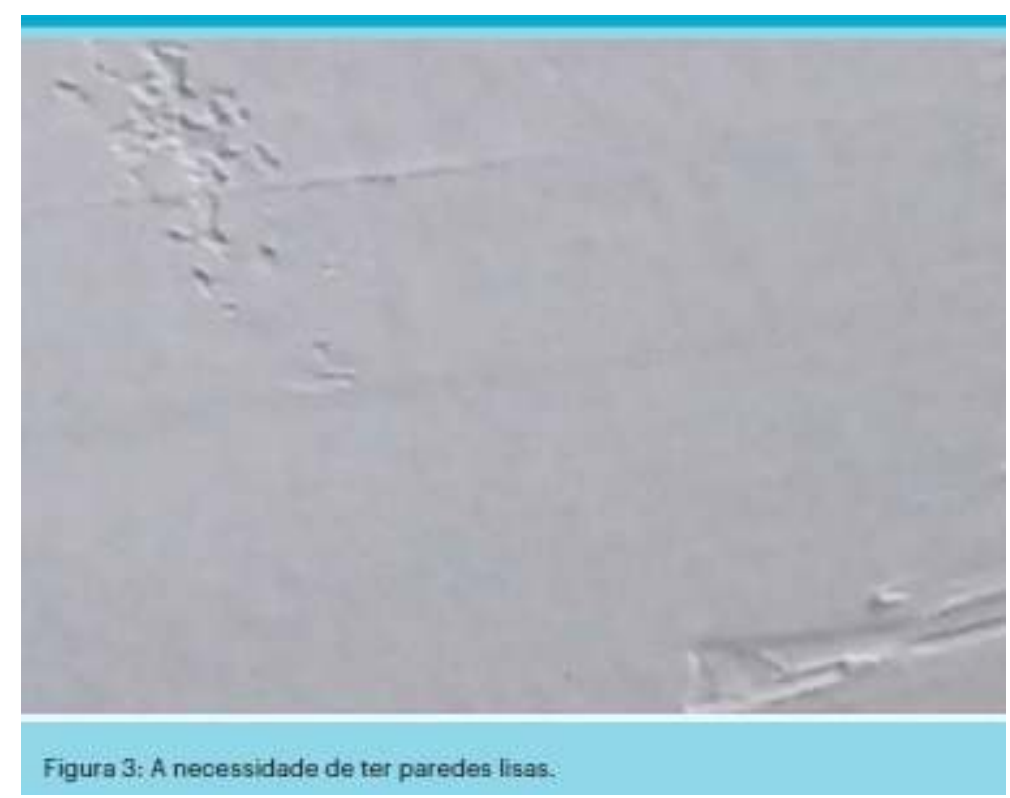

51 Quando a diretora de obra faz a inspeção dos estaleiros, ela pode constatar se o trabalho dos trabalhadores não foi efetuado, se o defeito continua presente. Neste caso, ela tira uma fotografia para envia-la e ou mostra-la às pessoas envolvidas, por exemplo, os vazamentos ao nível do teto não tinham sido reparados (cf. Figura 4). 
Figura 4: Um vazamento do teto a reparar

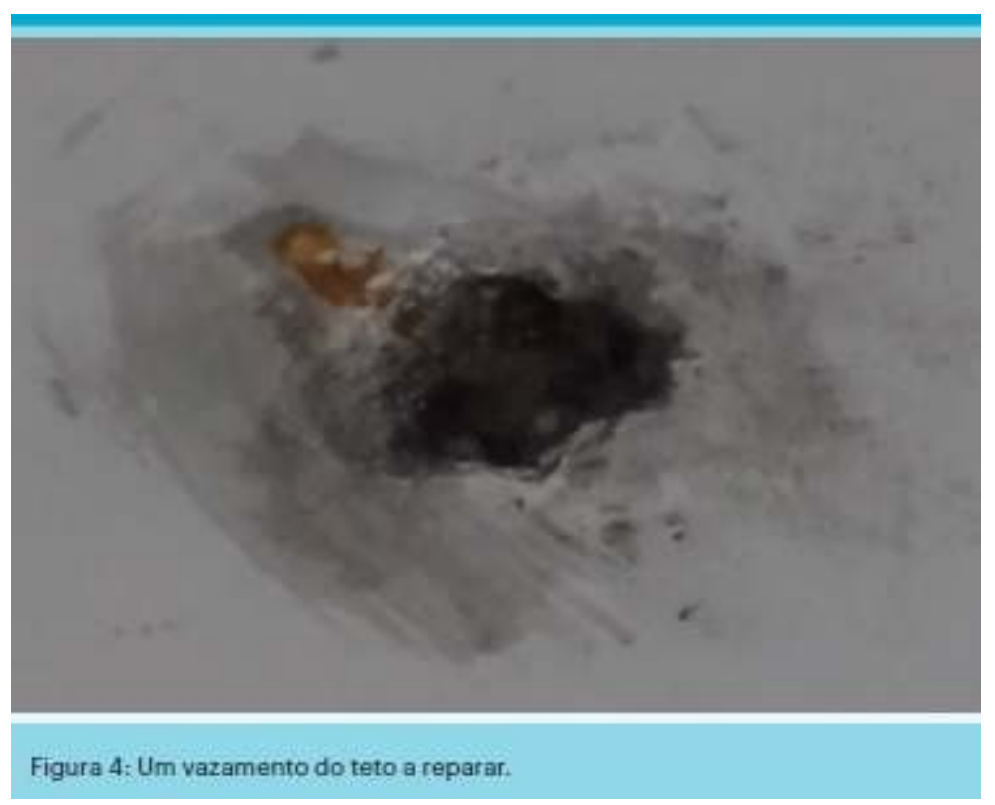

\subsubsection{A mobilização das corporações no estaleiro}

No estaleiro, o corpo serve de apoio para a compreensão, ou mesmo para a demonstração da ação para evitar ao máximo a quantidade de defeitos. As diretivas para evitar ou para o 'levantamento' das inconformidades realizam-se sempre através de diálogo. As trocas orais são o cimento da atividade no estaleiro. As inspeções ao estaleiro são omnipresentes na atividade de 'levantamento de inconformidades' a fim que a diretora de obra estabeleça trocas, de maneira informal, com os trabalhadores. Uma vez por mês, são realizadas reuniões entre a diretora de obra e os diretores de obra das empresas subcontratadas para realizarem um acompanhamento mais formal dos estaleiros. Havendo problemas maiores que não possam ser resolvido com seus interlocutores, a diretora de obra aciona os diretores gerais das empresas subcontratadas.

Vejamos agora como essa atividade de 'levantamento de inconformidades' se transformou quando um novo artefacto foi prescrito para a empresa.

\subsection{A transformação da atividade de 'levantamento de inconformidades'}

O objetivo da empresa de reabilitação é de inserir os instrumentos digitais na atividade dos diretores de obra para melhorar as suas condições de trabalho, fazendo-os ganhar tempo no quotidiano. A aplicação profissional, implementado num tablet portátil para o acompanhamento do 'levantamento de inconformidades' é desenvolvida por um fornecedor externo à empresa de reabilitação. Esse último criou uma aplicação para ajudar os atores da construção civil a antecipar e resolver os defeitos encontrados durante a vida da obra. Baseado na sua experiência de estaleiros, o fornecedor concebeu a aplicação, apoiando-se em necessidades reais dos diretores de obra. Uma conceção participativa com eles foi colocada em prática para permitir ajustes contínuos na aplicação. A partir de fevereiro 2018, todos os diretores de obra da empresa 
receberão a prescrição para usarem o aplicativo profissional. A vontade do Grupo é de desenvolvê-lo à escala nacional. Assim, pudemos observar o início do desenvolvimento desse aplicativo e identificar as primeiras transformações da atividade de 'levantamento de inconformidades' da diretora de obra.

O aplicativo profissional é unicamente destinado aos diretores de obra. Ela está disponível no Tablet e no telefone celular, mas esse último suporte ainda não foi usado pois o formato é pequeno para ser empregado convenientemente. Destacamos que os tablets portáteis não dispõem de outros aplicativos profissionais.

Apresentamos inicialmente o estudo comparado dos sistemas de atividade (Engeström, 1987) da diretora de obra que realizamos antes e depois da inserção do aplicativo profissional (4.2.1). Essa análise permitiu-nos de antever a natureza da transformação $(4.2 .2,4.2 .3)$.

\subsubsection{Evolução do sistema da atividade 'levantamento de inconformidades'}

Para ilustrar a evolução da atividade de «'levantamento de inconformidades', nossos resultados serão decompostos segundo os elementos do sistema de atividade de Engeström. Identificaremos uma evolução em vários pontos: o instrumento (I), a divisão do trabalho (D) et as regras (R) (cf. Figura 5).

Figura 5: A evolução do sistema de atividades de 'levantamento de inconformidades'

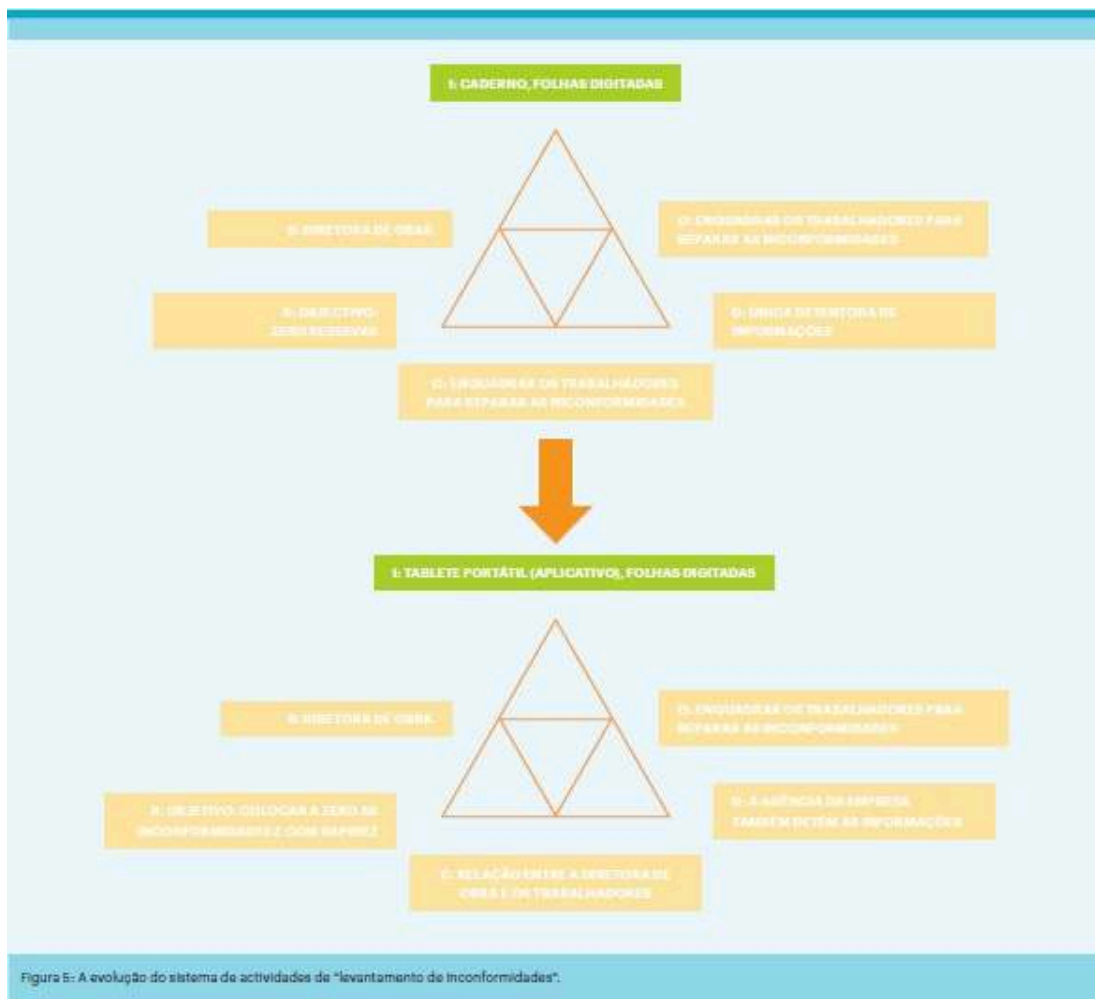


Figura 6: 0 uso de aplicativo profissional

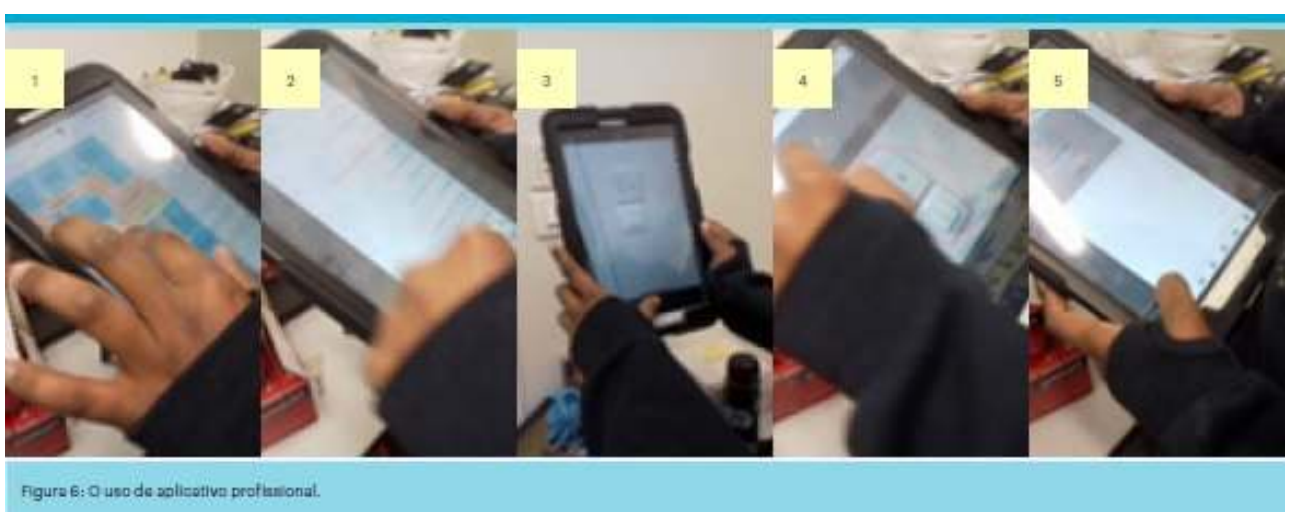

I(nstrumento). Antes: cadernos de notas, folhas datilografadas; Depois: tablet portátil (aplicação), folhas datilografadas

Com auxílio do caderno de notas e de uma caneta, a diretora de obra anota as reparações de trabalhos a efetuar: localização da inconformidade com o nome do edifício e do apartamento, natureza da inconformidade a ser reparada, assim que o nome da empresa que deverá efetuar a reparação. A lista de trabalhos a reparar é em seguida inserida no computador sob a forma de uma tabela e depois transmitida, pessoalmente, aos trabalhadores no estaleiro.

Com a aplicação profissional, quando a diretora de obra identifica uma inconformidade deve seguir várias etapas. Por exemplo, no estaleiro, ela constata que há um problema de ligações elétricas, pois os interruptores funcionam mal. $\mathrm{Na}$ aplicação, existe uma planta digital na qual ela vai selecionar o lugar onde é preciso agir (cf. 1 da figura 6). Ela vai em seguida procurar o nome da empresa que deve intervir com aquilo que deve fazer. Uma vez selecionadas essas informações (cf. 2 da figura 6), ela tira uma fotografia (cf. 3 da figura 6),assinala a vermelho os elementos que devem ser reparados (cf. 4 da figura 6) e depois prime no botão 'enviar' para gravar na aplicação (cf. 5 da figura 6). Quando os trabalhos são reparados, ela prime no botão 'levantar'.

Para utilizar o aplicativo profissional, a diretora de obra deve saber situar-se no plano digital, conhecer as corporações do ofício e os domínios de intervenção de cada empresa, para saber a quem atribuir os trabalhos. As inserções de dados podem ser feitas sem uso da rede internet e permanecem guardadas na memória da aplicação enquanto não forem 'levantadas'. Uma conexão internet é necessária para a atualização dos dados.

61 A diretora de obra usa a aplicação sempre que vai inspecionar o estaleiro para identificar os defeitos. No dia das OPR com o empreiteiro ela deve anotar todos os defeitos que ele repara, pois ele (também) usa um aplicativo profissional para o 'levantamento de inconformidades' de um fornecedor diferente (transmissão de dados digitais impossível entre os dois aplicativos).

62 A diretora de obra não somente teve que integrar um novo artefacto para a 'levantamento de inconformidades' mas esse último veio substituir o antigo suporte de papel. Isso obrigou-a a aprender novos gestos profissionais para utilizá-lo. Anteriormente, a diretora de obra tinha, de alguma maneira, a liberdade de escolher o 
suporte que preferia para fazer o acompanhamento do 'levantamento de inconformidades'. De agora em diante, o instrumento é imposto pela empresa.

\section{o(bjeto). Antes e depois: chefiar os trabalhadores para o levantamento de inconformidades}

Antes e depois da mudança, o objeto da atividade permanece o mesmo. Como destacamos, é uma parte da atividade diretora de obra de enquadrar os trabalhadores para que eles realizem os trabalhos de reparação nos prazos definidos.

\section{D(ivisão do trabalho). Antes somente detentora das informações Depois: a direção da empresa também possui as informações}

Antes da inserção da aplicação profissional, a diretora de obra, detinha as informações respeitantes às inconformidades a reparar. Ela não divulgava essas notas escritas.

De agora em diante, os dirigentes conhecem esses elementos. A aplicação gera uma classificação automática - identificando as inconformidades - que lhe são enviadas por e-mail semanalmente (cf. figura 7). o e-mail tipo da aplicação indica brevemente o número total de observações, por outras palavras: as inconformidades, assim como a percentagem de levantamentos. Para mais detalhes, um ficheiro Excel é anexado ao email. Neste, estão inscritos: o número da inconformidade, a localização da inconformidade, a corporação profissional e a empresa envolvida na reparação dos trabalhos, a descrição da inconformidade, se há uma fotografia anexada, a data na qual foi inscrita a inconformidade, o autor que a anotou, a data do 'levantamento as inconformidades', o ator que efetuou essas tarefas e o prazo de 'levantamento' em dias.

Figura 7: Email automático

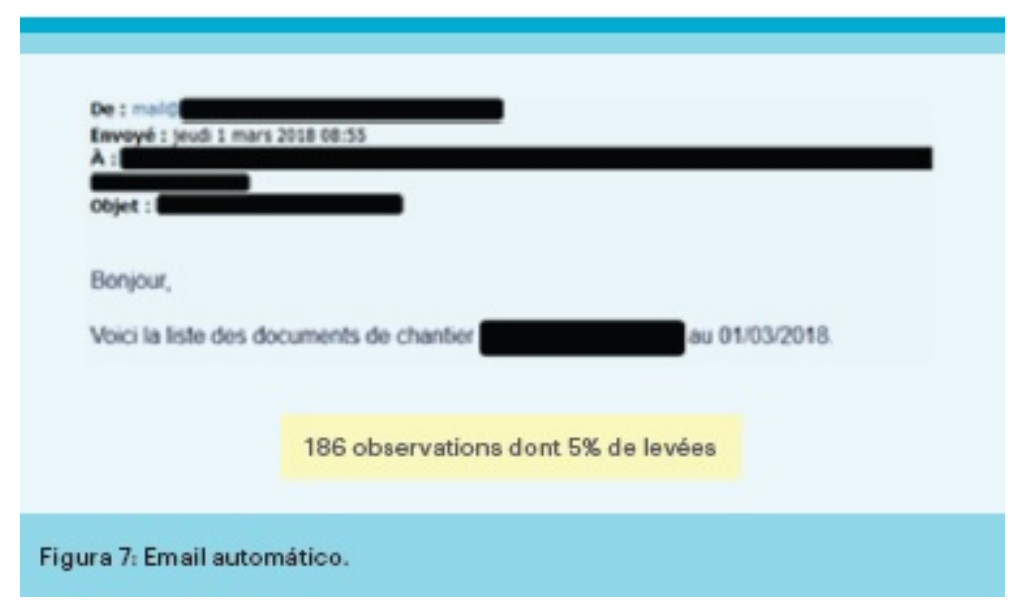

Anteriormente, quando a direção da empresa precisava obter os detalhes sobre as inconformidades, solicitava-os à diretora de obra. Atualmente, com o e-mail, ela dispõe de todas as informações. Por meio da visibilidade oferecida de uma parte da atividade da diretora de obra, a organização do trabalho torna-se pública. As pesquisas (Bobillier Chaumon, Cuvillier, Sarnin \& Vacherand-Revel, 2018) identificaram que as atividades dos executivos são cada vez mais transparentes com os instrumentos tecnológicos, o que tem como corolário o aumento do controle sobre a sua atividade. Efetivamente, os dirigentes podem usar o aplicativo profissional como um sistema panótico de controlo 
(Foucault, 1975). Isto foi claramente mencionado por um dirigente de empresa 'como recebemos semanalmente os reporting [refere-se ao e-mail enviado pela aplicação], podemos ver o número de inconformidades e, se na semana seguinte as inconformidades não forem levantadas, isso quer dizer que há um problema e nós vamos convocar o diretor de obra para saber de onde vem o problema'. Esta citação, permite de identificar uma 'prescrição da subjetividade' (Clot, 1999). Assim, a direção espera que o assalariado seja tão performativo quanto o instrumento tecnológico, ficando subentendido que é preciso fazer o levantamento de inconformidades mais rapidamente. Esse é também um desafio estratégico para a empresa poder identificar o que funciona ou não na atividade dos diretores de obra.

O espaço na hierarquia modifica-se e reinterroga as relações de poder (Crozier \& Friedberg, 1992), com um controle acrescido da atividade e a mudança introduzida pela visibilidade dada ao registo das inconformidades.

Neste momento, a diretora de obra não perceciona uma perda de autonomia nem uma amputação de sua responsabilidade porque continua a haver uma margem de liberdade possível. Por exemplo, ela não inscreve todas as inconformidades na aplicação profissional. Geralmente, os defeitos que serão reparados imediatamente não são inscritos. Durante as inspeções de estaleiro, se identifica uma inconformidade, menciona-a diretamente ao trabalhador que a repara imediatamente. A atividade ritmada do estaleiro não deixa tempo para inscrever uma inconformidade que será imediatamente reparada.

69 Ainda mais, se a direção tem maior controle da atividade da diretora de obra, essa última pode igualmente controlar mais facilmente a reparação dos defeitos dos trabalhadores. De facto, se eles não repararem as inconformidades, ela pode utilizar futuramente os 'rastos da aplicação' para efetuar advertências: data da inconformidade com a natureza da observação.

\section{C(ommunidade). Antes e depois: ligação entre a diretora de obra e os trabalhadores}

70 A diretora de obra está sempre em relação com a mesma comunidade no estaleiro: a dos trabalhadores das diferentes corporações profissionais.

\section{R(egras). Antes: Objetivo: zero inconformidades \\ Depois: objetivo: zero inconformidade e rapidamente}

71 Quer seja antes ou depois a obrigação de utilizar a aplicação profissional, o objetivo da qualidade é de não ter inconformidades a reparar. Com a aplicação profissional, a diretora de obra sabe que os dirigentes dispõem de um acesso para visualizar o tempo que demorou para levantar as inconformidades. Esse dado é integrado na sua ação, ela faz tudo para levantar as inconformidades o mais rápido possível. Ainda mais, a diretora de obra é obrigada a utilizar a aplicação profissional pois se nenhuma inconformidade é anotada, não haverá nada na classificação gerada pela aplicação e os dirigentes saberão.

72 Enfim, nos dois sistemas de atividade de 'levantamento de inconformidades' antes e depois, a diretora de obra procura chegar ao mesmo resultado: rececionar um imóvel que será conveniente para o cliente. A aplicação profissional fornece recursos para atingir mais facilmente e mais rapidamente o objetivo da qualidade do 'defeito zero'. 


\subsubsection{A mediação da atividade de 'levantamento de inconformidades': uma fonte de desenvolvimento...}

Utilizar a aplicação profissional para a atividade de 'levantar inconformidades' apresenta vários interesses.

A diretora de obra utiliza a classificação automática gerada pela aplicação profissional. Assim, ela dispõe de informações diretamente classificadas pelas empresas subcontratadas com os trabalhos que elas devem reparar. Essa classificação é um ganho de tempo para ela, pois permite organizar mais facilmente a interindependência das empresas no estaleiro. Pode programar as intervenções a serem realizadas com prioridade [fazer intervir o canalizador para concertar uma fuga que estragou a parede antes que a parede seja refeita pelo pintor]. Sua atividade encontra-se mais desenvolvida. Para a 'levantamento de inconformidades', ela consegue ser mais eficiente e mais performativa para identificar os defeitos que devem ser reparados pelos trabalhadores.

Como vimos, uma das atividades mais importantes da diretora de obra é a transmissão de informações aos trabalhadores. Para levantamento de inconformidades, é preciso agir rápido e isso subentende que as diretivas devem ser precisas. A aplicação profissional no tablete portátil elimina os inconvenientes da planta em papel. Efetivamente, alguns trabalhadores não compreendiam o que tinham que fazer por causa da dificuldade de localização espacial. Como sublinhamos, o uso das fotografias é muito desenvolvido, também aquelas resultantes da aplicação profissional foram rapidamente utilizadas. Se uma empresa subcontratada não tem muitas inconformidades a reparar, a diretora de obra pode acompanhar, no estaleiro, para com a ajuda das fotografias mostrar os trabalhos a reparar (cf. Figure 8).

Figura 8: As visitas ao estaleiro na presença do trabalhador

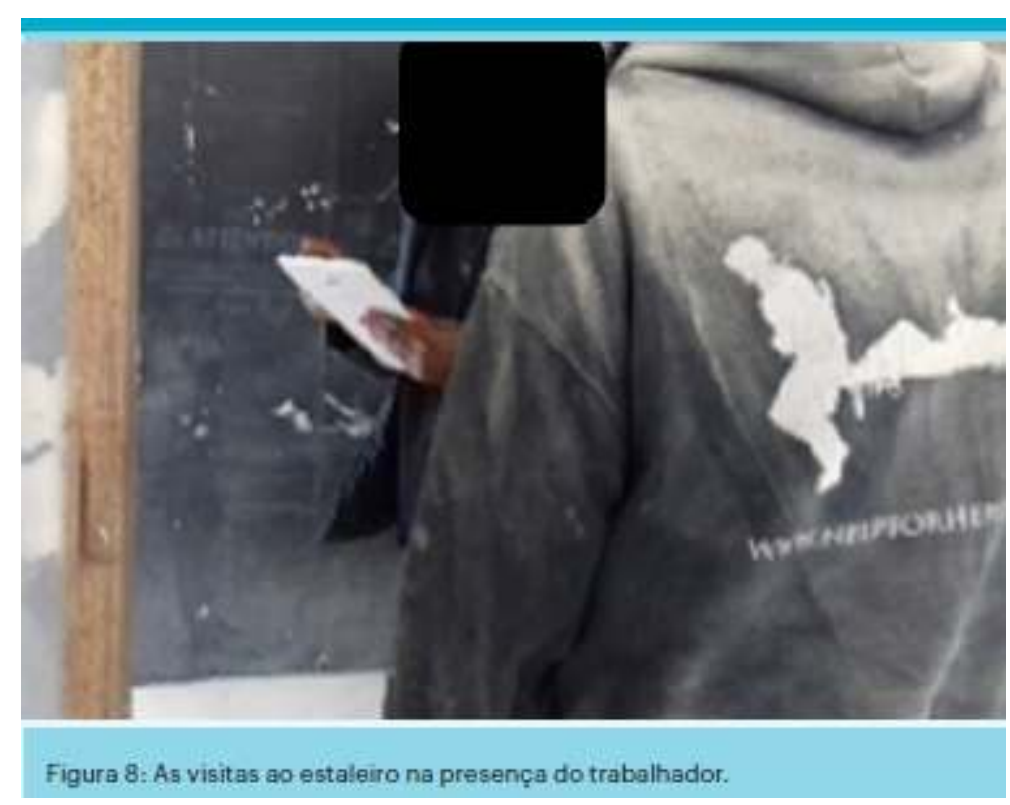

Pelo contrário, se uma empresa deve reparar muitas inconformidades, a diretora de obra não tem tempo de mostrar, no estaleiro, as inconformidades a reparar. Nesse caso, ela imprime as plantas numéricas e as fotografias resultantes da aplicação e transmite aos trabalhadores (cf. Figure 9). O suporte visual fala por si próprio, a diretora de obra 
não precisa fornecer explicações suplementares, isso é um ganho de tempo na transmissão das diretivas e consequentemente na reparação dos defeitos.

Figura 9: Os impressos provindo do aplicativo

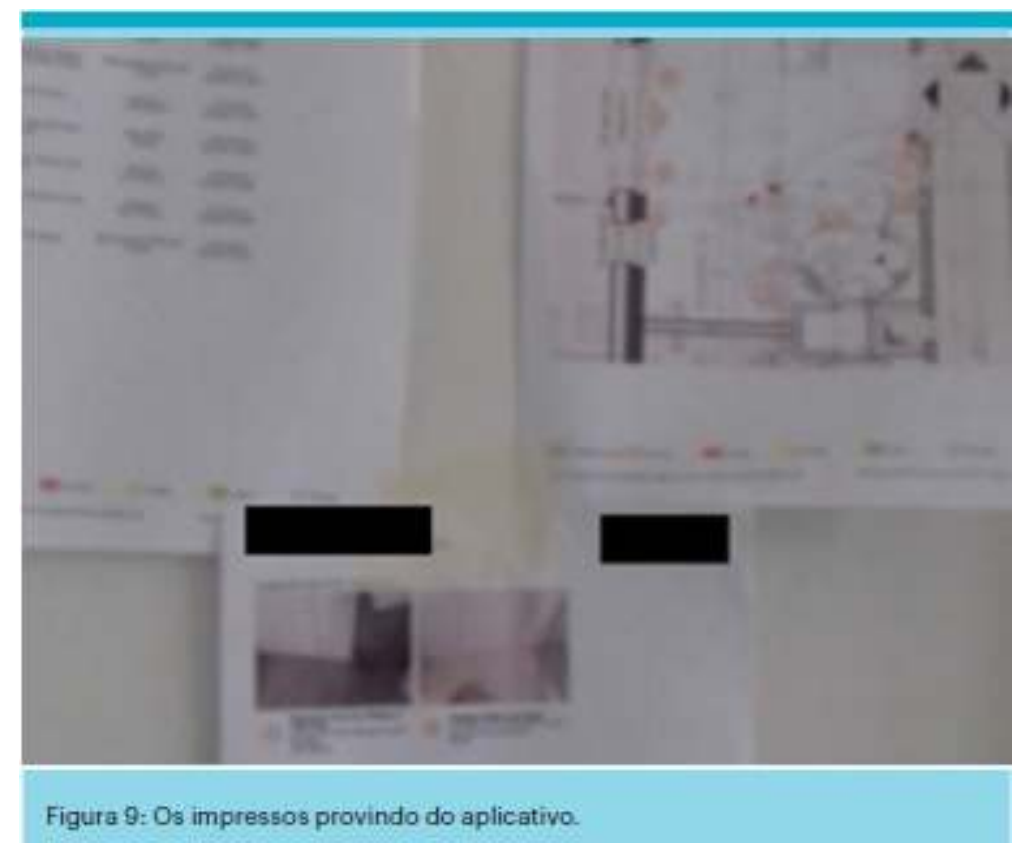

Como com o telefone celular, as fotografias são utilizadas para indicar aos trabalhadores o que eles devem realizar, mas a vantagem com a aplicação é que as fotografias são anexadas automaticamente à planta digital. Durante nossas observações, certos trabalhadores mencionaram que o suporte visual correspondendo ao lugar na planta digital (imprimido) no qual é preciso intervir era 'pratico' para evitar procurar no edifício onde se localiza o defeito.

As folhas imprimidas poderiam assemelhar-se a objetos intermediários (Vinck, 1999): elas servem de organização para os trabalhos a realizar. São portadoras de regras e de convenções específicas pois cada um sabe como intervir: por exemplo para que o pintor possa repintar a parede, necessitará de tal e tal tipo de materiais. Além disso, as folhas imprimidas ligam os trabalhadores à diretora de obra dado que por meio destes suportes, esta última ditava-lhes o que devem fazer. Aproximamo-nos aqui daquilo que Hutchins (1995) nomeou de cognição distribuída. De fato, a diretora de obra com a ajuda das folhas imprimidas coordena as atividades distribuindo-as entre os trabalhadores.

79 A aplicação profissional fornece recursos para atingir o objetivo de qualidade do 'defeito zero' mas gera também restrições.

\subsection{3... mas também novas atividades contrariadas}

Quando a empresa prescreveu a utilização da aplicação profissional para a atividade de 'levantamento de inconformidades', ela preconizou que os diretores de obra se formassem através de formações propostas pelo fornecedor.

81 Como sublinhamos, o trabalho no estaleiro assemelha-se a um trabalho por eventos, no qual a diretora de obra quase nunca tem descanso. É por isso que, desde que a aplicação 
profissional foi colocado em funcionamento no decurso de uma semana sobrecarregada na qual a diretora de obra tinha que fazer a gestão de vários imprevistos, ela não teve tempo de fazer a formação. Não queria que a atividade de 'levantamento de inconformidades' fosse prejudicada por uma perda de tempo ligada à assimilação da aplicação.

Apesar da formação que teve em seguida pelo fornecedor, foi necessário um tempo de adaptação para a utilizar eficientemente. De facto, no início, ela continuava a fazer suas inspeções de estaleiro com o tablet portável e o bloco de notas. Conservar o antigo suporte, o papel nesse caso, é muito frequente em processos de apropriação de uma tecnologia (Bobillier Chaumon, 2016). O antigo suporte é totalmente conhecido o que faz com que seja percebido como seguro (cf. Figure 10).

Figura 10: Coexistência de papel e mídia digital

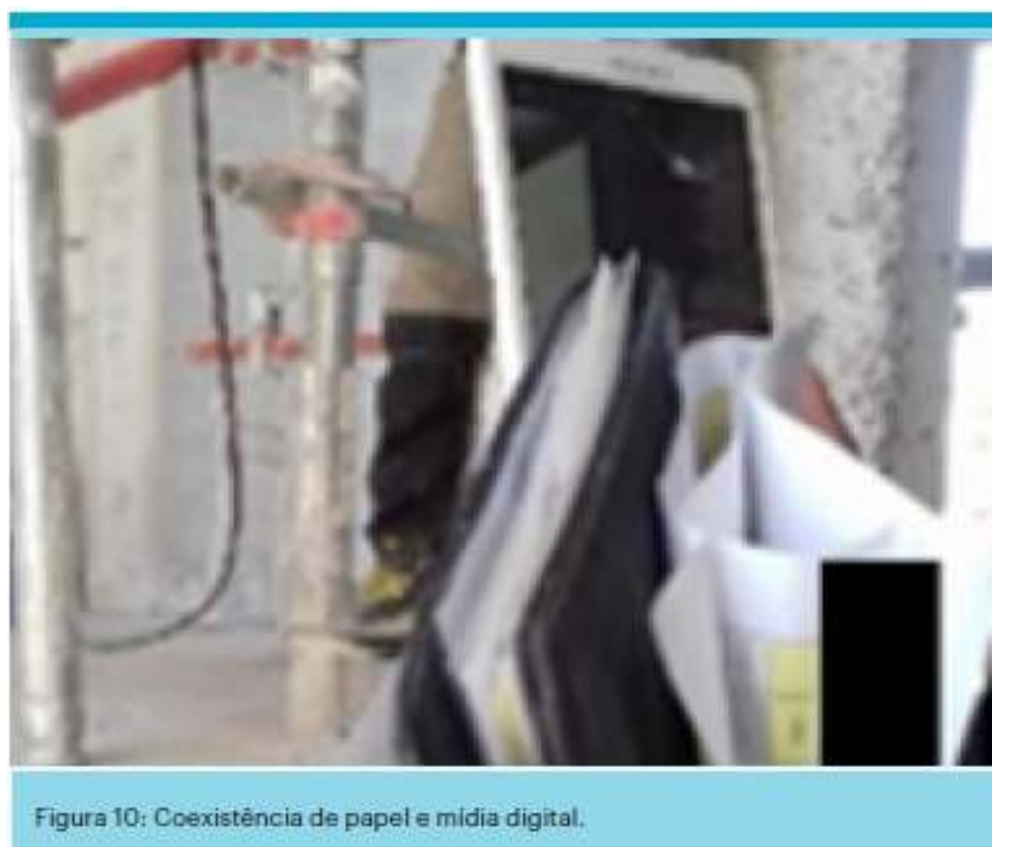

Como o dispositivo era desconhecido, a diretora de obra não confiava totalmente nele, temendo que ele não fornecesse todas as informações adequadas, contrariamente ao suporte de papel. Confirmamos aqui os resultados de alguns trabalhos (Boudokhane, 2006; Jauréguiberry, 2012), no sentido em que o indivíduo considera mais arriscado utilizar a tecnologia se não a julga suficientemente funcional e confiável.

Sabendo que os dirigentes têm acesso às inconformidades, com o envio de e-mail automático, o uso da aplicação profissional expropria a diretora de obra, pois ela não é mais a única detentora das informações. Um tal processo é muito frequente com a inserção de tecnologias digitais no trabalho (Bobillier Chaumon, Cuvillier, Sarnin \& Vacherand-Revel, 2018). O 'poder de agir' (Clot, 1999) da diretora de obra pode ser amputado se ela perde a autonomia na gestão das inconformidades.

Além disso, pensar em carregar o tablet acrescenta uma obrigação que vem intensificar e tronar mais densa uma atividade já muito sobrecarregada, ocasionando uma sobrecarga de trabalho (Lahlou, 2000). Enfim, como os roubos no estaleiro são muito frequentes, a diretora de obra deve integrar esse dado contextual ao seu uso. Ela 
precisa lembrar de não deixar o tablet visível e de trancá-lo no escritório se tiver que ir ao estaleiro sem ele.

Além dos interesses e das obrigações criadas pela utilização da aplicação, é preciso salientar que essa última é antes de mais uma ajuda para a atividade de 'levantamento de inconformidades' e que cabe ao chefe de orquestra do estaleiro adaptar-se às situações que encontra.

\subsection{A mediação digital da atividade de 'levantamento de inconformidades' testada no estaleiro}

Os principais objetivos para prescrever a aplicação profissional na atividade da diretora de obra para a 'levantamento de inconformidades' consistem em suprimir o papel para fazer ganhar tempo e precisão na transmissão de diretivas, mas isto não é sempre possível.

o fim do estaleiro é frequentemente um momento muito intenso em relação à atividade de 'levantamento de inconformidades', pois é preciso terminar com urgência os trabalhos. Para ganhar tempo e dinheiro, pode acontecer que a diretora de obra repare ela própria os defeitos e alguns trabalhos manuais são incompatíveis com a utilização simultânea de um tablet portátil. Por exemplo, ela tinha que fazer juntas de fixação ao nível do solo para evitar infiltrações de água. Ela não pôde utilizar a aplicação profissional para identificar onde ela devia colocar as juntas porque este trabalho exigia que ela tivesse as mãos livres e ela não devia sujar o tablet com as juntas que colam. Por essa razão, ela imprimiu as inconformidades no papel para ter as informações em permanência sob os olhos daquilo que tinha que ser ou não ser feito.

Além disso, o estaleiro é um lugar que não é necessariamente adaptado à utilização de instrumentos tecnológicos. Por um lado, a vida no estaleiro inscreve-se numa cultura em que as pessoas aprenderam a trabalhar sem o digital. Testemunham a omnipresença da palavra, dos movimentos, dos gestos, do papel. Por outro lado, as projeções de materiais ou de escombros podem vir a atingir o tablet portátil e quebrá-lo. É preciso portanto ter uma proteção sólida para proteger o instrumento digital.

Como sublinhamos, a particularidade dos estaleiros da empresa de reabilitação, é que todos os trabalhadores são subcontratados. Se devêssemos analisar o estaleiro em ação, a metáfora mais apropriada para descrever a cena da representação (Goffman, 1959) é, como sugeriram os atores no estaleiro, a de uma 'colmeia à procura de organização', formando uma situação complexa e dinâmica. Numerosos subcontratados ativam-se, coabitam e cruzam-se em diferentes lugares povoados de materiais e de objetos técnicos. A diversidade desses atores forma equipas compósitas multiprofissionais, multiculturais com contornos móveis no tempo e no espaço. Alguns não respeitam sempre a interdependência das tarefas, os modos operatórios e a gestão da coatividade com os outros subcontratados. Durante da nossa imersão, identificamos que com ou sem a aplicação profissional, o tempo gasto para reparar um defeito é o mesmo, dado que isso depende da vontade e da disponibilidade dos subcontratados para repararem a inconformidade. 


\section{Conclusão}

91 No setor da construção civil, em transição digital, estudamos a transformação da atividade de 'levantamento de inconformidades' de uma diretora de obra, após a introdução de uma aplicação profissional. A nossa investigação etnográfica permitiu compreender melhor essa atividade, tal como se realizada, se desenvolve e se sente na cena do estaleiro.

Procuramos identificar as condutas reais de adoção de uma tecnologia por um indivíduo ou um coletivo com vistas a estabelecer um retorno ao prestador pela conceção da aplicação (abordagem centrada no utilizador, Norman \& Draper, 1986). Seria necessário esperar que tenha havido mais desenvolvimento para identificar mais detalhadamente a maneira pela qual se insere a aplicação profissional na atividade de 'levantamento de inconformidades' e a maneira pela qual ela é suscetível de desenvolver essa atividade. Entretanto, na fase experimental atual de utilização, em referência aos trabalhos de Bobillier-Chaumon (2016), identificamos uma aceitabilidade prática (Tablet e aplicação facilmente manipulável, tendo em conta as necessidades) e uma aceitação situada (novas utilizações desenvolvidas).

Na perspetiva da investigação-ação, procuramos acompanhar e facilitar a transição digital. Nossa pesquisa permitiu à hierarquia identificar a necessidade de os diretores de obra disporem de um tempo de formação e de adaptação antes de se tornarem 'operacionais' para utilizarem as novas aplicações. Além disso, considerando o alto custo financeiro do desenvolvimento da aplicação nos estaleiros e o tempo humano de apropriação que ele gera, a empresa de reabilitação, procurou otimizar ao máximo seu funcionamento e mostrou-se preocupada em analisar com precisão a maneira pela qual ela se inseriu nas atividades de um estaleiro. Embora a sua utilização seja uma prescrição hierárquica da empresa, ela deu-se conta rapidamente que certos diretores de obra não o usavam ou mostravam reticências em fazê-lo. Na base dos nossos trabalhos e das discussões que permitiram, as mudanças preconizadas de forma positiva ou não, também puderam ser apreciadas mais finamente. Certos diretores de obra perceberam que havia reais vantagens em utilizar a aplicação (ganhos de tempo, precisão, etc.). Até ao momento não foi efetuada nenhuma devolução ao fornecedor uma vez que as funcionalidades da aplicação parecem adaptadas às práticas dos diretores de obra.

Em nossos próximos trabalhos, iremos pensar sobre as transformações da própria profissão de diretor de obra sob o efeito da mediação de sua atividade. Nessa perspetiva, pretendemos interrogar a maneira pela qual o BIM (maquete digital) reconfigura as modalidades colaborativas do diretor de obra com todos os atores que trabalham para a progressão do estaleiro até a receção do imóvel reabilitado. Quais serão as mudanças operadas nessa passagem de uma colaboração exclusivamente presencial para momentos de colaboração à distância ou inteiramente digitalizados? Como o diretor de obra utilizará essa maquete digital junto aos seus trabalhadores com o objetivo de qualidade compartilhado de rececionar um imóvel reabilitado com 'defeito zero'? 


\section{BIBLIOGRAFIA}

Becker, H.S. (2000). L'enquête de terrain: quelques ficelles du métier. Sociétés contemporaines, 40, 40, 151-164.

Béguin, P. (2004). Mondes, versions des mondes et mondes communs. Bulletin de psychologie, 57, 1(469), 45-59.

Bobillier Chaumon, M.E. (2016). Acceptation située des TIC dans et par l'activité : premiers étayages pour une clinique de l'usage. Psychologie du Travail et des Organisations, 22,1, 4-21.

Bobillier Chaumon, M.E., Cuvillier, B., Sarnin, P., \& Vacherand-Revel, J. (2018). Usage des TIC et évolutions des pratiques socioprofessionnelles des cadres: quels repères pour le métier et quelles incidences sur la santé? Pratiques Psychologiques.

Boudokhane, F. (2006). Comprendre le non usage technique: réflexions théoriques. Les Enjeux de l'information et de la communication, 1, 13-22.

Clot, Y. (2008). Travail et pouvoir d'agir. Paris: Presses Universitaires de France.

Clot, Y. (1999). La fonction psychologique du travail. Paris: Presses Universitaires de France.

Clot, Y., \& Gori, R. (2003). Catachrèse - Éloge du détournement. Nancy: Presses Universitaires Nancy. Crozier, M., \& Friedberg, E. (1992). L'acteur et le système. Paris: Points.

Cru, D. (2016). Le risque et la règle: le cas du bâtiment et des travaux publics. Toulouse: ERES.

Datchary, C. (2011). La dispersion au travail. Toulouse: Octarès.

Doniol-Shaw, G. (1997) Gestion des flux physiques et conditions de travail sur les chantiers. Paris: Plan construction et architecture.

Duc, M. (2002). Le travail en chantier. Toulouse: Octarès Editions.

Engeström, Y. (1987). Learning by Expanding: an activity-theoretical approach to developmental research. Helsinki: Orienta-Konsultit.

Forrierre, J., \& Six, F. (2010). Comprendre le risque routier professionnel par l'analyse de l'activité: l'exemple des conducteurs de travaux. Perspectives interdisciplinaires sur le travail et la santé, 12, 2, 1-27.

Foucault, M. (1975). Surveiller et punir. Paris: Gallimard.

Garfinkel, H. (1987). Ethnomethodological Studies of Work. London: Routledge.

Goffman, E. (1959). The Presentation of Self in Everyday Life. New-York: Doubleday Anchor.

Goffman, E. (1971). Relations in Public. New-York: Micro-studies of the Public Order. New-York: Basic Books.

Goodwin, C., \& Goodwin, M. (1996). Seeing as a situated activity: formulating planes. In Y.Engeström \& D. Middleton (Ed.), Cognition and Communication at Work (pp. 61-95). Cambridge: Cambridge University Press.

Grosjean, M., \& Lacoste, M. (1999). Communication et intelligence collective. Le travail à l'hôpital. Paris: Presses Universitaires de France. 
Grosjean, S., \& Groleau, C. (2013). L'ethnographie organisationnelle aujourd'hui. De la diversité des pratiques pour saisir l'organisation en mouvement. Revue internationale de psychosociologie et de gestion des comportements organisationnels, 48, 13-23.

Guffond, J.L., \& Leconte, G. (2001). Le pilotage d'activités distribuées: le cas du chantier. Sociologue du travail, 43, 197-214.

Hutchins, E. (1995). Cognition in the Wild. Massachusetts: The MIT Press.

Ianeva M. (2013). La restructuration du travail chez Santé Info : du développement de l'activité d'un centre de contact spécialisé à ses incidences sur les pratiques situées. Activités, 10, 1, 243-247. Ianeva M., \& Vacherand-Revel, J. (2015). Développement de l'activité et travail d'articulation : le cas d'un centre d'appels médico-social. Pistes: Perspectives interdisciplinaires sur le travail et la santé, $17,1,1-23$.

Ianeva, M., Vacherand-Revel, J., \& Licoppe, C. (2017). Accounting for Activity Development through Perspectives in an Inbound Call Center. Journal of Workplace Learning, 29, 5, 428-446.

Jauréguiberry, F. (2012). Retour sur les théories du non-usage des technologies de communication. In S. Proulx \& A. Klein (Ed.), Connexion: communication numérique et lien social (pp. 335-350). Namur: Presses Universitaires de Namur.

Lahlou, S. (2000). La cognition au travail et ses outils: débordement, révolution, distribution. Intellectica, 30, 7-17.

Lave, J. (1988). Cognition in practice. New-York: Cambridge University Press.

Norman, D.A., \& Draper, S.W. (1986). User Centered System Design: new perspectives on HumanComputer Interaction. Hillsdale: Lawrence Erlbaum associates.

Rabardel, P. (1995). Qu'est-ce qu'un instrument? Les Dossiers de l'ingénierie éducative, 19, 61-65.

Rouleau, L. (2013). L'ethnographie organisationnelle d'hier à demain. Revue internationale de psychosociologie et de gestion des comportements organisationnels, 48, 27-43.

Schütz, A. (1987). Le chercheur et le quotidien. Paris: Klincksieck.

Six, F. (2016). L'ergonome et le chantier. Toulouse: Octarès Editions.

Star, S.L., \& Strauss, A. (1999) Layers of Silence, Arenas of Voice: The Ecology of Invisible Work. Computer Supported Cooperative Work (CSCW), 8, 1-2, 9-30.

Suchman, L. (2007). Human-Machine reconfigurations. Plans and situated actions, 2 nd ed. Cambridge: Cambridge University Press.

Vacherand-Revel, J. (2017a). Le travail coopératif d'équipes de projet d'ingénierie à l'épreuve de l'activité en réunion médiatisée et multi-localisée. Psychologie du Travail et des Organisations, 23, 2 , 89-116.

Vacherand-Revel, J. (2017b). Le travail en équipe à l'ère de sa médiatisation numérique: figures actuelles de l'innovation organisationnelle. Psychologie du Travail et des Organisations, 2, 23, 85-88.

Vacherand-Revel, J. (2015). Travailler en interaction avec et via les technologies numériques ou pour en concevoir d'autres: vers une ethnographie psychologique des activités médiatisées. Mémoire d'Habilitation à Diriger des recherches. Université de Lyon.

Vacherand-Revel, J. (2003). Le travail coopératif inter-entreprises médiatisé par les TIC: des espoirs suscités.à l'épreuve de la réalité. In G. Karnas, C. Vandenberghe \& N. Delobbe (Ed.), Actes 
du 12ème congrès international de psychologie du travail et des organisations, Vol. 3 (pp. 447-456).

Louvain-la Neuve: Presses Universitaires de Louvain.

Vacherand-Revel, J. (1995). L'articulation du social et du cognitif dans l'interaction personnemachine en situation de travail. Psychologie du travail et des Organisations, numéro thématique: travail et automatisation, 4, 1, 17-26.

Vilette, M. (2014). Ethnographie dans l'entreprise. Annales des Mines - Gérer et comprendre, 3, 117, 4-9.

Vinck, D. (1999). Objets intermédiaires dans les réseaux de coopération scientifique. Contribution à la prise en compte des objets dans les dynamiques sociales. Revue française de sociologie, 40, 2, 385-414.

\section{NOTAS}

1. BIM: "Building Information Management".

2. O empreiteiro é mandatado pelo cliente para assegurar o acompanhamento da conceção e da realização dos trabalhos.

3. Não detalharemos todas as atividades que estão sob a responsabilidade do diretor de obra, mas somente aquelas que julgamos pertinentes no contexto de nossa pesquisa.

4. Literalmente, nós usamos "estar lá" com o sentido de habitar, de "viver no terreno", para podermos ter dele um conhecimento aprofundado.

5. A especificidade da empresa de reabilitação é a de que no conjunto dos seus estaleiros, os trabalhadores são todos subcontratados.

\section{RESUMOS}

O setor de construção está claramente a entrar na transição digital com a vontade de passar do papel para o completamente digital. A nossa pesquisa visa estudar a transformação da atividade de 'levantamento de inconformidades' de uma diretora de obra usando um aplicativo especializado. Para apreender a complexidade dessa atividade, uma abordagem sistémica pareceu relevante e propusemos uma articulação teórica entre as dimensões situadas e incorporada da atividade e seu desenvolvimento histórico-cultural. Realizamos uma investigação etnográfica, durante seis meses, em imersão num estaleiro, sob a forma de uma observação participante em paralelo com uma observação de tipo 'shadowing'. Os principais resultados indicam que a atividade de 'levantamento de inconformidades' faz parte de uma cultura marcada pela importância dos intercâmbios e das corporações. $O$ aplicativo especializado transforma essa atividade que por vezes é desenvolvida e por outras vezes é contrariada. São os diretores de obra que têm de adaptar o uso do aplicativo às situações do estaleiro.

El sector de la construcción está claramente haciendo la transición digital con la voluntad de pasar del papel al totalmente digital. Nuestra investigación tiene como objetivo estudiar la transformación de la actividad de 'levantamiento de reservas' de una directora de obra utilizando una aplicación informática. Para entender la complejidad de esta actividad, un enfoque sistémico parecía evidente y propusimos una articulación teórica entre las dimensiones situadas y 
encarnadas de la actividad y su desarrollo histórico-cultural. Llevamos a cabo una investigación etnográfica, durante seis meses, en inmersión en una obra, con una participación observadora y una observación en 'shadowing'. Los resultados indican que esta actividad forma parte de una cultura caracterizada por la importancia de los intercambios y de las corporaciones. La aplicación experta transforma esa actividad que a veces se desarrolla y otras se impide. Los directores de obra tienen que adaptar el uso de la aplicación a las situaciones de la obra.

Le secteur du Bâtiment entre davantage dans la transition numérique avec la volonté de passer du papier au tout numérique. Notre recherche a pour but d'étudier la transformation de l'activité de 'levée de réserves' d'une conductrice de travaux utilisant une application métier. Pour saisir la complexité de cette activité, une approche systémique nous a semblé pertinente et nous avons proposé une articulation théorique entre les dimensions situées et incarnées de l'activité et son développement historico-culturel. Nous avons réalisé une investigation ethnographique, durant six mois, en immersion sur un chantier, sous la forme d'une participation observante en parallèle d'une observation en 'shadowing'. Les principaux résultats indiquent que l'activité de 'levée de réserves' s'inscrit dans une culture marquée par l'importance des échanges et du corps. L'application métier transforme cette activité qui se trouve parfois développée et parfois contrariée. C'est aux conducteurs de travaux d'adapter l'usage de l'application aux situations du chantier.

The building sector is clearly undergoing the digital transition with the willingness to move from paper to absolute digital. Our research aims to study the transformation of the activity of 'lifting of reservations' of a construction site manager using a business application. To grasp the complexity of this activity, a systemic approach seemed relevant and we proposed a theoretical articulation between the situated and incorporated dimensions of the activity and its historicalcultural development. We carried out an ethnographic investigation, for six months, in immersion on a construction site, in the form of an observant participation along with a shadowing observation. The main results indicate that the activity of 'lifting of reservations' is part of a culture marked by the importance of the exchanges and the corporations. The business application transforms this activity which is sometimes strengthened, and other times thwarted. The construction site managers must adapt the use of the application to the site situations.

\section{ÍNDICE}

Mots-clés: psychologie du travail, ethnographie, construction, médiatisation numérique

Palabras claves: psicologia del trabajo, etnografía, sector de la construcción, mediadores digitales

Keywords: work psychology, ethnography, construction, digital mediators

Palavras-chave: psicologia do trabalho, etnografia, setor da construção, mediatização digital

\section{AUTORES}

\section{ELODIE CHAMBONNIĖRE}

Laboratoire GRePS - Université Lumière Lyon 2

5, Avenue Pierre Mendès France, 69500 Bron, France

elodie.chambonniere@univ-lyon2.fr 


\section{JACQUELINE VACHERAND-REVEL}

École Centrale de Lyon - Laboratoire GRePS

36, Avenue Guy de Collongue, 69134 Écully, France

jacqueline.vacherand-revel@ec-lyon.fr

BRUNO ANDRIEU

Laboratoire GRePS - Université Lumière Lyon 2

5, Avenue Pierre Mendès France, 69500 Bron, France

bruno.andrieu@gmail.com 